\title{
A NEW SPECIES OF ERIOPHYID MITE FROM BRAZIL (ACARI: TROMBIDIFORMES)
}

\author{
Jeferson Mineiro ${ }^{1}$, Carlos Flechtmann ${ }^{2}$ \\ ${ }^{1}$ APTA, Instituto Biológico, Centro Avançado de Pesquisa em Proteção de Plantas e Saúde Animal. Campinas, São \\ Paulo State, Brazil \\ E-mail: jefmin@hotmail.com \\ ${ }^{2}$ Senior Professor, Department of Entomology and Acarology, Escola Superior de Agricultura "Luiz de Queiroz", \\ University of São Paulo, Piracicaba, São Paulo, Brazil \\ E-mail: chwflech@usp.br
}

\section{ABSTRACT}

On a survey of plant mites in the State of São Paulo, Brazil, a vagrant eriophyid mite on the leaves of Luffa cylindrica was collected and proved to be new for Science. It is here in described and figured.

Keywords: Eriophyidae, Luffa cylindrica, description

\section{UMA NOVA ESPÉCIE DE ÁCARO ERIOFIÍDEO DO BRASIL (ACARI: TROMBIDIFORMES)}

\section{RESUMO}

Em um levantamento de ácaros de plantas no Estado de São Paulo, Brasil, um ácaro eriofiídeo vagrante foi coletado de folhas de Luffa cylindrica e que se revelou novo para a Ciência, e é aqui descrito e ilustrado.

Palavras-chave: Eriophyidae, Luffa cylindrica, descrição

\section{INTRODUCTION}

During a prospection of plant mites we came across a sample of eriophyid mites from Luffa. So far non species of eriophyid mites was reported from this plant. The examination proved this mite to be new for Science and is herein described.

\section{MATERIAL AND METHODS}

A sample of six specimens of an eriophyid mite was collected from leaves of Luffa cylindrica Roemer (Cucurbitaceae) in Paulinia. São Paulo, Brazil GP $22^{\circ} 46^{\prime} 39.333^{\prime \prime}$ S, $47^{\circ}$ 
5'53.613" W, 629m, by Dr. A. Raga. Mites were mounted in a modified Berlese medium (AMRINE JR \& MANSON, 1996) on a microscope slide. It was kept on a heating plate at circa 60 Celsius for a week, for clarification and drying. Examination of the specimens were made by means of a phase-contrast microscope Dialux 20 and an interference microscope Nikon Eclipse $80 i$, at magnification of 1000 in immersion oil. Line drawings were made with the aid of a drawing tube. Measurements, in micrometers, were taken with an ocular grid calibrated with a slide micrometer and refer to the length of the structures, unless specified otherwise. Measurements are of holotype and ranges of paratypes, in parentheses; dorsal semi-annuli were counted from the first annulus behind the prodorsal shield rear margin; ventral semi-anuli from the first annulus behind caudal end of genitalia. The terminology and description used for this mite follows mainly Amrine Jr et al. (2003). Deposited in the Mite Reference Collection of Escola Superior de Agricultura “Luiz de Queiroz”, Piracicaba, São Paulo, Brazil.

\section{RESULTS AND DISCUSSION}

\section{Taxonomy}

Family Eriophyidae Nalepa, 1898

Subfamily Phyllocoptinae Nalepa, 1892

Tribe Calacarini Amrine \& Stasny, 1994

Genus Calacarus Keifer, 1940

Calacarus ragai Flechtmann \& Mineiro, 2021 nov. spec.

\section{Diagnosis}

Calacarus ragai nov. spec. is unique in presenting the prodorsal shield ornamentation made of lines delimiting clearly 12 fields or cells: medio longitudinally one anterior hexagonal cell followed by an elongate rectangular cell flanked on its rear half by an elongate triangular cell on each side. Laterally a row of four quadrangular cells on each side on shield. Opisthosoma with smooth dorsal annuli and more numerous ventral annuli, densily microtuberculate. Empodium five-rayed.

\section{Description}

FEMALE $(n=6)$ (Figure 1). 

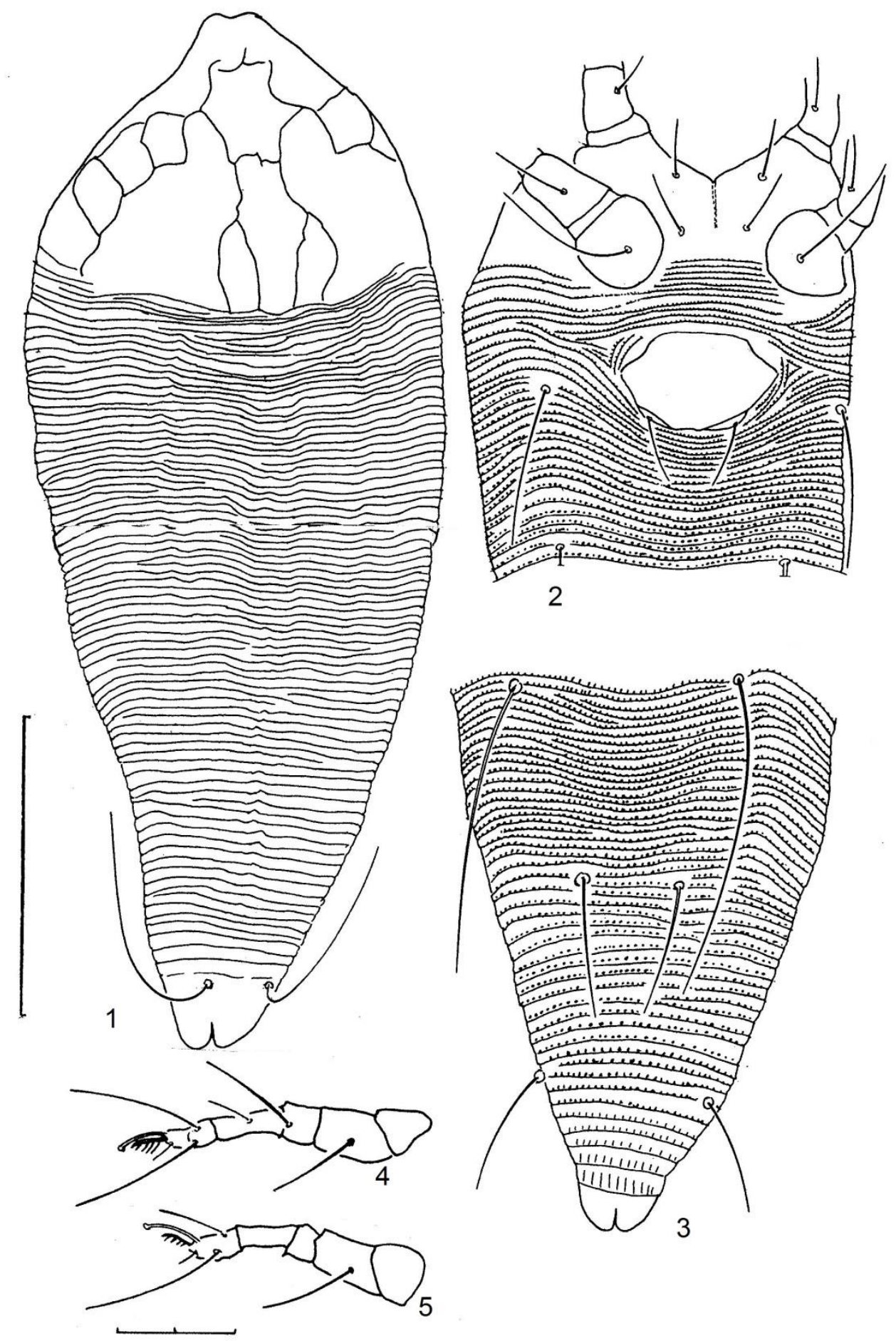

Figure 1. Calacarus ragai nov. spec., female. 1 - dorsal habitus; 2 - coxigenital region; 3 opisthosomal ventral region, Scale bar $50 \mu \mathrm{m}$; 4 - leg I; 5 - leg II, scale bar $20 \mu \mathrm{m}$. 
Body length 179 (172-189), width 71 (70-71), robust, fusiform. Gnathosoma: curved ventrad; pedipalp coxal seta (ep) 9 (9); chelicerae 28 (26-31). Prodorsal shield 49 (48-49) long, 64 (6469) wide. Ornamentation made of lines delimiting clearly 12 fields or cells: mediolongitudinally one anterior hexagonal cell, followed by an elongate rectangular cell flanked by an elongate triangular cell on each side of its rear half. Laterally a row of four quadrangular cells on each side of shield. Fontal lobe 9 (9-11) long, anteriorly concave. Legs with all usual setae present except genual seta II. Legs I 40 (36-40); femur 11 (10-11), femoral seta (bv) 14 (13-17); genu 5 (4-5), genual seta ( $\left(l^{\prime \prime}\right) 31$ (28-31); tíbia 10 (8-10), tibial seta $\left(l^{\prime}\right) 5(5-6)$; tarsus 7 (6-7), lateral seta $(f t$ ") 25 (24-25), dorsal seta $\left(f t^{\prime}\right) 20$ (20-24), unguinal seta $\left(u^{\prime}\right) 4$ (4-5), solenidion slightly curved, knobbed, 7 (7-9), empodium 6 (6-7), 5-rayed. Legs II 34 (31-34), femur 10 (10), bv 13 (11-14); genu 4 (3-4), l' missing; tibia 8 (8-9); tarsus 6 (6-7), ft" 22 (22-23), ft' 9 (9-11), u' 5 (5-6), solenidion 9 (8-10), curved, knobbed; empodium 7 (7-8), 5-rayed. Coxisternal region with 13 (12-13) annuli, microtuberculate, microtubercles small, beadlike. Coxal seta I (1b) 13 (13-14) apart, 8 (8-10) long; coxal seta II (1a) 11 (10-11) apart, 12 (11-12) long; coxal seta III (2a) 29 (29-30) apart, 35 (35-40) long. Coxisternal apodeme 8 (7-8). Genitalia 17 (17-18) long, 28 (2628) wide, epigynum smooth. Genital seta $(3 a) 18$ (16-18). Opisthosoma with three weak longitudinal ridges, dorsal annuli 81 (81-83), smooth and ventral annuli 75 (68-75), densily microtuberculate; microtubercles small, beadlike, becoming elongate in caudal 5 (4-5) annuli. Lateral seta (c2) 33 (31-33), on annulus 1 (1-2); ventral seta I (d) 42 (38-42) apart, 54 (51-54) long, on annulus 22 (19-23); ventral seta II (e) 17 (16-18) apart, 24 (23-25) long, on annulus 50 (42-50); ventral seta III (f) 28 (25-28) apart, 22 (22-26) long, on annulus 68 (61-68) or $6^{\text {th }}$ from rear. Caudal seta (h2) 49 (48-49); accessory setae (hl) missing.

Type material: holotype female, 5 paratype females, on one microscopic preparation.

Relation to host plant: vagrant on undersurface of leaf.

Etymology: We take pleasure in naming the new species for Dr. Adalton Raga, Researcher and Extensionist for plant health and who collected and submitted the specimens. 


\section{Remarks}

In one species, Calacarus malvae Mohanasundaram, 1983 opisthosomal annuli are equal dorsal-ventrally and entirely microtuberculate. In C. helus Keifer, 1969, C. millingtoniae Mohanasundaram, 1982, C. mussaendae Keifer, 1977, C. pelargonii Keifer, 1974 and C. speciosissimum Flechtmann, 1999 (2000) opisthosomal dorsal (smooth) and ventral (microtuberculate) annuli are equal in number. In all other described species there are more ventral annuli than dorsal. Most Calacarus species have the propodosomal shield design as an irregular pattern of lines or lines delimiting more than 20 fields or cells. The prodorsal shield design of the new species resembles somewhat the one of $C$. helus Keifer, 1969, C. flagelliseta Flechtmann, Moraes \& Barbosa, 2001 and C. pelargoni Keifer, 1974. The new species differs from $C$. helus in presenting the anterior lobe of the prodorsal shield concave (blunt in $C$. helus) and in the absence of prodorsal tubercles (clearly indicated in $C$. helus); it differs from $C$. flagelliseta in having a 5-rayed empodium (6-rayed in C. flagelliseta) and in presenting 13 annuli in the coxigenital region (8-9 in $C$. flagelliseta). The new species differs from $C$. pelargoni in having the prodorsal shield lines smooth (with short right angle dashes appended to the central lines in $C$. pelargoni), in the medially excavated anterior shield lobe (lobe semicircular in $C$. pelargoni) and in the 5-rayed empodium (6-rayed in C. pelargoni).

\section{REFERENCES}

AMRINE JR., J.W.; MANSON, D.C.M. 1996. Preparation, mounting and descriptive study of Eriophyoid mites.In: LINDQUIST, E.E.; SABELIS, M.W. (Eds.) Eriophyoid mites. Their biology, natural enemies and control. Elsevier, Amsterdam pp.383-396.

AMRINE JR., J.W.; STASNY, T.A.H.; FLECHTMANN, C.H.W. 2003 Revised keys to world Genera of Eriophyoidea (Acari: Prostigmata). Indira, Michigan, 244p.

FLECHTMANN, C.H.W.; KREITER, S.; ETIENNE, J.; MORAES, G.J. 1999. Plant mites (Acari) of the French Antilles. 4. Eriophyidae (Prostigmata). Acarologia, Montpellier, v.40, n.3, p.321-342.

KEIFER, H.H. 1940. Eriophyid Studies X. Bulletin of the California Department of Agriculture, California, v. 29, p.160-179.

KEIFER, H.H. 1969. Eriophyid studies C-3. Agricultural Research Service, U.S. Department of Agriculture, Washington, $24 \mathrm{pp}$.

KEIFER, H.H. 1974. Eriophyid Studies C-9. Agricultural Research Service, U.S. Department of Agriculture, Washington, $24 \mathrm{pp}$.

KEIFER, H.H. 1977. Eriophyid Studies C-14. Agricultural Research Service, U.S. Department of Agriculture, Washington, $24 \mathrm{pp}$.

MOHANASUNDARAM, M. 1982. Four new species of Phyllocoptine mites (Eriophyidae: Acarina: Acarina) from Tamil Nadu, India. Entomon, Kerala, v.7, n.1, p.23-30. 
MOHANASUNDARAM, M. 1983. Indian Eriophyid Studies. IV. Record of new Phyllocoptine mites (Phyllocoptinae: Eriophyidae: Acarina) from South India. Acarologia, Montpellier, v.24, n.1, p.13-35.

Received in: February, 3, 2021

Accepted in: May, 12, 2021 